\title{
1.2 \\ HUR BILDEN AV ETT VÄRLDSARV \\ KONSTRUERAS
}

\author{
Johan Knutsson och Anneli Palmsköld
}

För att förstå hur vissa gårdar i Hälsingland kom att betraktas som och utnämnas till världsarv är det angeläget att reda ut hur kategorin och begreppet "hälsingegårdar" skapades. Vilken materialitet har hälsingegården förknippats med? Vad har bevarats och av vilka skäl? Hur såg musealiserings- och kulturarvsprocessen ut från identifiering och dokumentation, via forskning och medial förmedling, fram till nomineringen av sju hälsingegårdar som världsarv?

\section{Begreppet "hälsingegård"}

Ordet "hälsingegård" är relativt nytt och började användas som ett jämförande begrepp i början av 1900-talet. Utgivningen av Svenska Allmogehem (Carlsson \& Molin 1909) var ett led i statsmakternas försök att stävja emigrationen genom att agitera för bättre bostäder åt befolkningen på landsbygden. Boken är både en historisk översikt av den svenska allmogens byggnadskultur från norr till söder och en samling praktiska anvisningar och råd för den som kände sig manad och kapabel att bygga sitt eget hem. I redogörelsen för olika byggnadstyper, presenterade som karaktäristiska för olika landskap, används genomgående de sakligt upplysande begreppen "gård i Hälsingland", "bruksarbetarebostäder i Dalarna", "hantverkaresmåbruk i Uppland" och så vidare. Landskapsidentiteten var här en viktig ingrediens i bygget av den gemensamma nationella identiteten, som vilade på idén om att de olika landskapsspecifika särarterna tillsammans utgjorde nationen Sverige (jfr Lundström 2005b; Knutsson 2010:5of; Palmsköld 2017).

I Svenska Turistföreningens årsskrift tre år senare, 1912, använde arkitekten John Åkerlund olika gårdsbeteckningar där landskapens 
namn ingick: "Jämtlandsgård", "Hälsinglandsgård", "Ölandsgård", "Gotlandsstuga" och så vidare (Åkerlund 1912). Bidraget är ett sammandrag av en längre text som samma författare publicerade i boken Gamla svenska allmogehem, som gavs ut samma år (Tengbom et al. 1912). Det är i denna bok som begreppet "hälsingegård" första gången förekommer i text (Olsson 2002). I Svenska Turistföreningens årsskrift 1923, där landskapet Hälsingland utgör bokens tema, använde etnologen Sigurd Erixon begrepp som "hälsingebönder", "hälsingeformer" och "hälsingemåleri" - dock ej "hälsingegård" (Erixon 1923). Men ordet hänger liksom i luften.

Exemplen ovan pekar på uppfattningar om Hälsinglands kultur ur ett nationellt perspektiv. En liknande process ägde rum lokalt och regionalt. I Hälsinglands fornminnessällskaps protokoll från 1904 används till exempel benämningen "Helsingestuga". Ordet avsåg interiören till en envåningsbyggnad som då inrättades i fornminnessällskapets tillfälliga museilokaler i Hudiksvall, "hvarvid de af bruksförvaltaren P V Hägg och bankkamrer A Johansson skänkta målade taket och väggbonaderna kommo väl till pass" (Hälsinglands fornminnessällskaps arkiv, protokoll 28 december 1904). Det då i stort sett oprövade begreppet "hälsingegård" skulle snart komma att etableras. Det användes i Helsingerunor 1921 då en serie med presentationer av ett antal gårdar inleddes. I varje årgång och under rubriken "Gamla helsingegårdar" beskrevs utvalda gårdar i ord och bild, däribland en av de gårdar, Kristofers i byn Stene i Järvsö socken, som numera ingår i världsarvet. Anna Lindegren, som var aktiv som folkbildare och hembygdsforskare i norra Hälsingland, använde därefter uttrycket i en av sina essäer från 1925 (HM, Anna Lindegrens arkiv).

Ytterligare exempel på hur begreppet kom att etableras är 1940 års utgåva av Svenska gods och gårdar som behandlar Hälsingland, där artikeln "Hälsingegårdar" ingår (Ohlén et al. 1940). När Karl Cajmatz i Svenska Turistföreningens årsskrift 1965, med fokus på landskapet, beskriver Hälsinglands "bondeslott" använder han på ett självklart sätt begreppet hälsingegård. Härefter kan begreppet betraktas som etablerat. Det har sedan dess flitigt använts inom den kulturvårdande sektorn, i museibranschen, i hembygdsföreningarnas verksamhet och av den intresserade allmänheten.

Martin Paju menar i sin avhandling Hälsingegården i omvandling. En studie av världsarvsprocessen $i$ Hälsingland (2016), att begreppet används i tre olika betydelser: för en hel jordbruksfastighet, ett byggnadskom- 
plex med flera byggnader eller för en enskild, rikt dekorerad mangårdsbyggnad (Paju 2016:83). Han menar vidare att begreppet kan "förstås som ett samlande koncept för de konstruerade minnen som samhället önskar behålla" (ibid. 2016:89). Billy Höök menar i uppsatsen Rum för fest och föreställning. Framställningen av världsarvet Hälsingegårdar (2015) att det trots att det "inte beskriver något enhetligt" ändå används för att vinna trovärdighet. I processen fram till utnämnandet av världsarv var det viktigt att företeelsen framställdes "som en enhet som passar in i världsarvskonventionens taxonomi" (Höök 2015). I denna kulturarvsprocess etablerades begreppet också i ett internationellt sammanhang.

\section{Vad är en hälsingegård?}

Det finns en ofta kommunicerad idealbild av vad som kännetecknar en hälsingegård, liksom det finns en föreställning om hur en bergsmansgård, en gotlandsgård eller mellansvensk herrgård bör se ut. Det är uppenbart att det för den stora allmänheten är den enskilda huvudbyggnaden som numera får symbolisera företeelsen "hälsingegård", det vill säga att begreppet i första hand syftar på en viss sorts byggnad eller byggnadstyp - inte en gårdstyp (Olsson \& Thelin 2000:19; jfr Daun \& Ahlberger 2018; Nyström et al. 2018). Det är en bild som förstärks av de gårdar som representerar Världsarvet Hälsingegårdar - de välbärgade bondgårdarna med fokus på den konstnärliga rumsgestaltningen, skapad för fest. Samtidigt leder begreppet "hälsingegård" tankarna till just en gård: en gårdsfyrkant (en "fyrbyggd" gård) med en två våningar hög huvudbyggnad, försedd med en rikt utsmyckad förstukvist och många fönster. På ena sidan om gårdstunet ligger undantagsstugan och på den andra säng- eller gäststugan, kanske sammanbyggd med fähuset. Gårdstunet nås genom portlidret i en loge- och stallbyggnad. Lador, härbren, smedja och övriga ekonomibyggnader finns spridda i närområdet utanför den centrala fyrkanten.

I princip motsvaras denna bild av den anläggning som på 1930-talet rekonstruerades på friluftsmuseet Skansen med hjälp av byggnader från olika byar i Delsbo och Ljusdals socknar. Skansen och Nordiska museet ingick då i samma organisation och arbetet med flytt, återuppförande och inredning hade planerats av etnologen Sigfrid Svensson som arbetade vid Nordiska museets dåvarande allmogeavdelning (Nilson 2001:52). Ett omsorgsfullt arbete lades ned för att skapa en trovärdig berättelse om "Delsbogården" - om husen och deras innehåll, hur de 
har brukats och av vem. Stor möda lades också ned på att anpassa varje detalj med antikvarisk noggrannhet. Det handlade om att "få tillsamman ett puzzle, där bitarna utgöras av de möbler som stå till buds och de uppgifter man har om deras placering och användning", som Nordiska museets Elisabeth Strömberg beskrev det (Strömberg 1941:155). Brandförsäkringsprotokoll med utförliga gårdsbeskrivningar från åren 1853-1865 ingick i källmaterialet inför uppbyggandet och "minnesgoda gamlingar ha lämnat den bästa hjälp i arbetet", enligt Skansens sakkunnige i byggnadsfrågor Gotthard Gustafsson (Gustafsson 1941:127f). I sitt tal vid invigningen av Skansens Delsbogård lät dåvarande ecklesiastikministern Arthur Engberg den bli utgångspunkt för mer allmängiltiga reflektioner kring den svenska bondgården som "en uppsummerad tradition, ett stycke historia", vittnesbörd om hårt arbete men också om "skaparglädje, av liv och förnyelse" och om bondgården som "det konstnärliga arbetets källsprång" (Engberg 1941:112ff). Talet förmedlade en idealbild som uttrycker en spridd uppfattning om vad som gjorde den typiska bondgården i allmänhet och hälsingegården i synnerhet.

Skansens hälsingegård, Delsbogården, gestaltar en gårdstyp och en idé om hur en sådan borde ha varit inredd med folkligt måleri, folkliga möbler och folkliga inredningstextilier. Resultatet är alltså en ideal version av konceptet hälsingegård. Men mycket av det måleri som vi idag förknippar med en sådan gård har aldrig varit tänkt för en tvåvåningsbyggnad med stora fönster, rödmålad panel och förstukvist med klassicerande formspråk, såsom dessa utformades kring mitten av 1800-talet. Några av de mer namnkunniga hälsingemålarna, som Paul Hallberg (1734-1789), Jonas Hertman (1755-1804) och den mest kände av dem alla, Gustaf Reuter (1699-1783), var verksamma under en tid då boningshusen var byggda som betydligt mer anspråkslösa parstugor i en våning. I dessa fanns dagligstugan, eller "barstugan" till vänster och helgdagsstugan, herrstugan eller "harrstugan" till höger. Även om byggnader i två våningar kunde uppföras i enstaka fall under sent 1700-tal, då rödfärg började förekomma, var det den omålade timrade parstugan $i$ en våning utan panel som dominerade. Denna enklare version äger lika stor rätt till beteckningen hälsingegård, som de mer extravaganta byggnaderna från 1800-talets mitt.

De flesta av de omkring tusen gårdar som i världsarvsansökan omtalas som hälsingegårdar, är inte några museimiljöer. De ägs av privatpersoner som lever och bor i dem. På så sätt kan gårdarna betecknas som levande kulturarv. Interiört är de fyllda av ting som speglar olika 


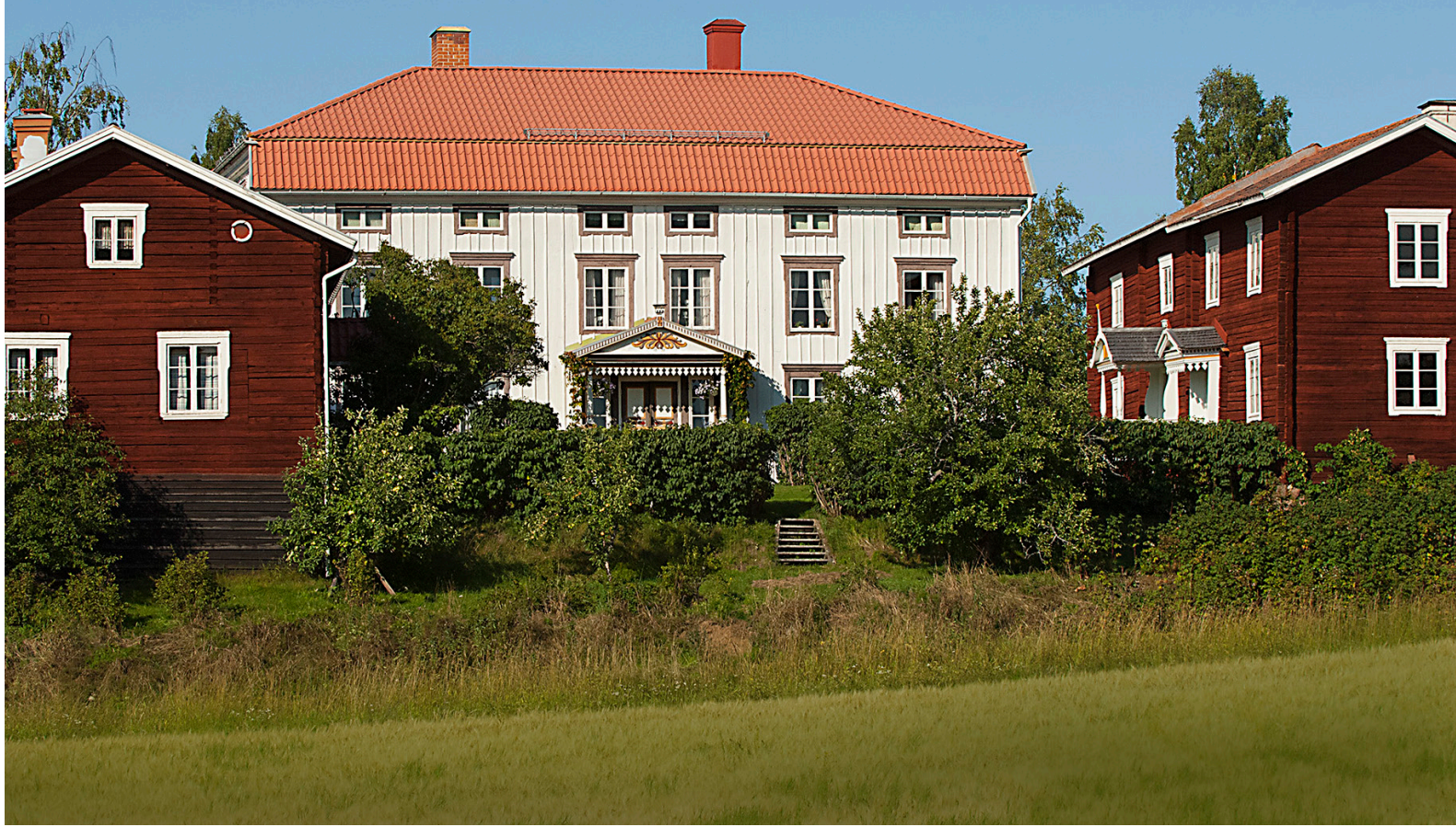

tider - framför allt vår egen. Vissa rum kan dock vara bevarade och iordningställda som museala miljöer. I många fall vårdas också släktklenoder såsom målade möbler av sina ägare. Men den mest typiska hälsingegården idag har genomgått ett flertal förändringar, anpassningar och moderniseringar sedan de en gång uppfördes.

\section{Hälsingegården som ett uttryck för överflöd och överdåd}

Föreställningen om ett samband mellan ett områdes natur och egenskaperna hos de människor som lever där etablerades under 1800-talet. När forskningen om den folkliga inredningskulturen utvecklades i början av 1900-talet var det självklart att förklara en rik folkkonst med ett allmänt välstånd, i sin tur ett resultat av naturens förutsättningar på platsen. Skånes möbelmåleri ansågs till exempel "drypa av den skånska jordens ymnighet" medan möbleringen av den norrländske bondens stuga ansågs bära en fläkt av "viddernas storhet", som sveper in i stugan för att ge "lynne och inredning sin rytm". Så kunde möbelskaparen Carl Malmsten uttrycka saken (Malmsten 1916:86). Men det fanns också sedan lång tid tillbaka en idé om att naturen i sig med dess landskapsformationer och växtliv, "djurrikets och växtverldens alster, bergsmas-

Figur 1 (1.2.1):

Pallars Världsarvsgård. Foto: Annika Röstberg Hagelin 
sornas linier, flodernas art, himmelens utseende" (Ålund 1875:247), präglade människans uppfattning om skönhet. Ett landskaps naturförhållanden ansågs skapa människans "kynne", vilket i sin tur påverkade utseendet hos folkkonsten och gårdens arkitektur. Detta tankegods från 1800-talet levde kvar länge. I sitt tal till invigningen av Skansens Delsbogård berörde Arthur Engberg de olika provinsernas "byggnadsskick" som "i sin utveckling lytt under samma lagar som språk, sedvänja, klädedräkt och konst", det vill säga "speglat själva själsarten, syftningen och hållningen hos bygdens folk" (Gustafsson 1941:112). Detta synsätt förekommer ibland fortfarande, som i beskrivningen av konstnärerna Karin och Carl Larsson, som "liksom de folkliga konstnärerna" visste "att färgerna måste stämma med landskapet och ljuset" (Rydin 2009:61). Att konstnärsparet Larsson kunde tänka i de banorna är fullt möjligt. Men det är förmodligen en romantiserande tanke att folkkonstens utövare skulle ha gjort det. De anpassade sin färgskala efter tillgången på pigment, moden och konventioner - men knappast efter landskapets karaktär och ljus.

Överhetens uppfattning att hälsingebornas självbild manifesterades $i$ ett extraordinärt byggande har en lång historia. Under 1600 - och tidigt 1700-tal uppmärksammades de stora och påkostade byggnaderna (Fiebranz 2003). Från 1700-talets mitt börjar detta beskrivas som något negativt. Bönderna beskylldes för att de genom ett "överflödigt" byggande förorsakade ett onödigt slöseri med skog som bättre behövdes för kol till järnframställningen. Från och med 1700-talets mitt uppmanade myndighetspersoner till begränsningar av byggandet för att bättre hushålla med skogen som råvara. Ett exempel på detta finns i Pehr Schisslers bok Helsinga hushåldning (1749). Där beskrivs hur bönderna gärna bygger hus med flera rum "mera för anseendet än nödvändigheten" (citerat efter Olsson 2002:44). I en liknande skrift om Gästrikland beskriver samme författare (Schissler 1769) hälsingeböndernas sätt att bygga som "överflödigt" och mest med sikte på att kunna "hålla gästabud" (citerat efter Olsson 2002:47). Detta sätt att bygga stack troligen i ögonen på statsmakterna, då det samtida ståndssystemet satte ramarna för vad som var lämpligt levnadssätt för respektive stånd.

Bilden av ett överdrivet påkostad byggande i Hälsingland stärks genom resenärers berättelser (Höök 2015:37) och de lokala kronobefallningsmännens svar på landshövdingens frågor om förhållandena i sina respektive områden. Alfta socken beskrivs 1790 som "väl byggt, till och med överflödigt" (citerat efter Bedoire \& Hogdal 2000:9f). I kritiken 
av ett, som det uppfattades, opassande och onödigt överdåd, skärptes tonläget ytterligare efter 1800-talets mitt. Länets hushållningssällskap beskrev då de stora gårdarnas "gagnlösa" och "oinredda" byggnader som uttryck för "en fåfänga, som lyser med det stora och granna istället för att med till det yttre mindre i ögonen fallande, men desto mera trevliga, bekväma och ändamålsenliga hem befrämja och underlätta husflit och lantlig verksamhet" (citerat efter Bedoire \& Hogdal 2000:60f).

\section{Den antikvariska resan och räddningsaktionen - inventering, vård och dokumentation}

Hälsinglands "allmogekultur" uppmärksammades tidigt av de antikvarier som under 1800 -talets industrialiseringsprocess betraktade sitt uppdrag som en räddningsaktion för ett hotat kulturarv. Bland de regionala aktörerna märktes främst Helsinglands fornminnessällskap, grundat 1859 av prosten Lars Landgren (1810-1888) i Delsbo. Sällskapet var länge den nordligaste av landets fornminnesföreningar (Arcadius 1997:84). Tonvikten i verksamheten låg från början på dokumentation av lokala dialekter och insamling av forntida föremål. De sistnämnda utgjordes framför allt av medeltida kyrklig konst från kyrkorna i landskapet (se Falkstedt 1980:38ff), "hvilka objekt inom ganska kort tid utan tvifvel skulle blifvit tillintetgjorda" (Hälsinglands fornminnessällskaps arkiv, protokoll 16 september 1862). På så sätt avvek inte Hälsinglands fornminnessällskap från andra fornminnessällskap. I ett protokoll nämns de "goda och dyrbara bilder och målningar" (Hälsinglands fornminnessällskaps arkiv, protokoll 16 december 1861) som samlats in från bland andra Delsbo, Norrbo, Bjuråker, Tuna och Njutångers kyrkor (Hälsinglands fornminnessällskaps arkiv, protokoll 23 augusti 1861). En av de första uppgifterna blev att rädda och iordningställa Enångers gamla medeltidskyrka som ett museum för kyrklig konst (Falkstedt 1980:40ff; Nylander \& Abenius Falkstedt 2009:5). Denna uppgift står med i fornminnessällskapets stadgar av vilka också framgår att kyrkan ifråga var ställd under Kongl. Vitterhets-, Historie- och Antiquitetsakademiens "beskydd och öfverinseende" (Stadgar för Helsinglands Fornminnes-Sällskap). Ett liknande beslut fattades i Enångers sockenstämma den 22 maj 1859 (Hälsinglands fornminnessällskaps arkiv, protokoll 18 september 1862 ). Bilderna och målningarna som hade samlats in från olika kyrkor transporterades vidare till Enångers kyrka där materialet samlades. 
Vid sekelskiftet 1900 hade fornminnessällskapets insamlingsverksamhet utökats till att också omfatta bohag, dräkter, seldon och vapen. I årsberättelsen från 1903 står det: "För att i tid rädda hvad som ännu finnes qvar af gamla allmogeföremål hafva flera socknar genomrests af sällskapets sekreterare" (Hälsinglands fornminnessällskaps arkiv, årsberättelse 1903). Återkommande noteringar vittnar om de "träbesmaner", "kafveldon" och andra enklare föremål som nu började tillföras samlingen vid sidan av de mer spektakulära, "forntida" och konstnärliga objekten. Samlingens tillväxt speglas i årsberättelser, men också i de kataloger som gavs ut. Här framgår det på ett mer övergripande plan vilka föremålskategorier som ansågs värdefulla nog att samla in och dokumentera. Även i detta avseende stämde inriktningen hos Hälsinglands fornminnessällskap med vad som gällde inom landets övriga fornminnessällskap (Arcadius 1997:113). Den stämde också överens med Artur Hazelius direktiv till sina "skaffare" enligt vilka de äldsta och mest dekorerade föremålen skulle prioriteras (Hazelius 1873).

Insamlingsarbetet var omfattande. Senare skulle man från centralt håll framhålla resultatet som "ett rikhaltigt och mångsidigt uttryck för den gamla helsingekulturen och torde vid en jämförelse med öfriga Norrlandssamlingar knappast stå tillbaka för någon" (Hälsinglands fornminnessällskaps arkiv, skrivelse från tillförordnade riksantikvarien 1926). Det publika intresset ökade, liksom antalet besökare som ville ta del av samlingarna. Och medlemsbasen stärktes. Även i detta avseende återspeglade verksamheten en allmän tendens. En vanlig trend i början av 1900-talet var utvecklingen "från smala och elitistiska föreningar med en relativt begränsad verksamhet till bredare organisationer som bedrev en varierad och mer publik verksamhet" (Lundström 2005a). En metod som användes var att efter förebild från Skansen och Nordiska museet visa allmogeföremålen i sin miljö (jfr Palmsköld 2007:105ff). Vid en av de fester som i Hudiksvall iscensattes kring sekelskiftet 1900 till förmån för en ny museibyggnad, uppfördes en stuga från Delsbo i stadsträdgården. Den inreddes med möbler och föremål ur fornminnessällskapets samlingar (Falkstedt 1981:28).

Förutsättningen för att kunna visa samlingarna var ett nytt hus, en för ändamålet uppförd museibyggnad eller åtminstone större lokaler än de rum i stadens läroverk man först disponerade. Detta var också en förutsättning för att kunna samla in fler föremål. Under decennierna kring sekelskiftet katalogiserades bortåt 10000 allmogeföremål (Nylander \& Abenius Falkstedt 2009:8). År 1897 föreslog arkitekten Agi Lindegren 
att en byggnadsfond borde bildas med "syfte att, när så kunde ske, i Hudiksvall uppföra ett museum" (Hälsinglands fornminnessällskaps arkiv, protokoll 30 december 1897). Det skulle dock dröja innan frågan fick sin lösning. Och någon ny museibyggnad uppfördes aldrig. Under perioden 1903-1936 fanns istället museet inrymt i Hudiksvalls gamla sjukhus och 1937 flyttade samlingarna in i de för ändamålet iordningställda lokalerna i Helsingebankens gamla byggnad som byggts till med två flyglar.

På 1920-talet fanns långtgående planer på att skapa ett friluftsmuseum i Hudiksvall. Grunden till ett sådant var redan lagd, bland annat "genom förvärvande i sista stund [...] av en synnerligen märklig mangårdsbyggnad från Delsbo med väl bibehållen fast inredning, såsom sängar, hyllor och bänkar samt vägg och takmålningar" (Hälsinglands fornminnessällskaps arkiv, inkommande skrivelser 1927, skrivelse till Kungl. Maj:t från Gästrike-Hälsinge hembygdsförbund, koncept). Den byggnad som avsågs var Tjärnmyrastugan, då omtalad som "en gammal mangårdsbyggnad från Tjernmyra by i Delsbo", som grosshandlaren Karl Berg i Hudiksvall 1918 skänkt till sällskapet (Hälsinglands fornminnessällskaps arkiv, protokoll 8 mars 1918). Tjärnmyrastugan återuppfördes på Köpmanberget strax öster om Hudiksvall där den fick sällskap av ett par timmerbyggnader från Hudiksvalls stad. Stugan flyttades en andra gång 1950, denna gång till Delsbo forngård.

Inom den svenska kulturminnesvården och museiverksamheten ökade intresset för inredningskultur och inomhusmiljöer under 1920-talet. Att skapa sådana var en utställningsmetod som innebar att så kallade kulturhistoriska miljöer byggdes upp (jfr Palmsköld 2007:105ff). På Nordiska museet försköts till exempel intresset från den unika och märkvärdiga detaljen till helheter och sammanhang. Ett exempel är hur dalmålningar kom att samlas in. Istället för att förvärva enstaka dalmålningar samlades nu hela rumsinteriörer in. Samtidigt dokumenterades dalmålningarnas ursprungliga placering, deras brukskontext. De uppmärksammades på så sätt snarare som viktiga delar av en inredning, det vill säga som delar av ett större sammanhang istället för enskilda kulturhistoriska dokument. I Nordiska museets meddelanden presenterades de inte längre som ett visst antal utan som en samlad helhet (Knutsson 1995:38). Detta nya sätt att betrakta föremål och inredningar är synligt även i Hälsinglands fornminnessällskap. I sällskapets museilokaler byggdes miljöer med väggmålningar upp (Nylander \& Abenius Falkstedt 2009:8) och i verksamhetsberättelsen från 1923 anges att årets resor "ha i främsta rummet varit inriktade på efterforskningar 
av väggbonader, takmålningar och dyl.” (Hälsinglands fornminnessällskaps arkiv, Verksamhetsberättelse 1923).

Samtidigt som ett större fokus lades på föremålen i sina sammanhang, tilltog intresset för målningarnas konstnärliga kvaliteter och uttryck. Begreppet folkkonst började användas för att beteckna vissa resultat av konstnärliga aktiviteter i folkliga miljöer. Fram till 1920-talet användes folkkonstbegreppet mycket sparsamt. Man talade om allmogekonst - i konsekvens med benämningen av annan materiell kultur förknippad med folkkulturen, som allmogebåtar, allmogetextilier etcetera. Ordet folkkonst är en akademisk konstruktion, som har varit både omdebatterad och ifrågasatt. Inom tyskt språkområde användes begreppet vid 1800-talets mitt och sporadiskt även tidigare (Bringéus 2005). Det var dock i Alois Riegls bok Volkskunst, Hausfleiss und Hausindustrie från 1894 som ordet på allvar lanserades i den akademiska forskningen och diskursen (Riegl 1894/1978). Riegl anses allmänt ha varit först med att söka en bestämning av folkkonstbegreppet och en avgränsning av företeelsen gentemot annan konst. Sedan tog det ytterligare ett par decennier innan begreppet slog igenom.

Vad var det då som avsågs med allmogekonst eller folkkonst? Gränserna var flytande men av det som ingick i Hälsinglands och andra områdens folkkultur var det främst interiörmåleriet som räknades dit. I litteraturen kunde folkliga möbler behandlas under rubriker som "Bohag och heminredning" medan rubriken "Allmogekonst" var reserverad för dalmålningar och snidade friargåvor. Folkdräkter ingick inte i konceptet, inte heller det som hade med det immateriella kulturarvet, som till exempel tro, sedvänjor, berättande och hantverksprocesser, att göra. Textilier var ett kapitel för sig, ofta presenterat som slöjd utövad av kvinnor som besatt en kollektiv kunskap i textilt görande, i en kontext utan individuella aktörer (jfr Palmsköld 2005a \& b). Begreppet folkkonst har kritiskt granskats (se Rosenqvist $2007 \mathrm{ff}$ ), men samtidigt använts och etablerats inte minst i de kulturhistoriska museernas verksamhet. Här har det använts som ett sorteringsinstrument när samlingar dokumenteras och registreras, men också i utställningssammanhang. Länsmuseerna började arbeta med olika specialområden baserade på traktens specifika historia, vilken skildrades i arkiv, föremålssamlingar, utställningar och trycksaker (jfr Arcadius 1997). I Hälsinglands fall var det folkkonsten som särskilt lyftes fram.

Alternativa begrepp har förts fram som till exempel visuell folklig kultur (Höök 2015) och populärkonst (Londos 2005). Vad som bör 
betecknas har diskuterats, om det handlar om historiska företeelser eller om det även rör samtiden. I denna antologi har vi valt att använda begreppet folkkonst i bemärkelsen konst av folk på landet för folk på landet där så är relevant och begreppet visuell folklig kultur eller inredningskultur där detta är motiverat.

Den svenska folkliga textilkonsten tilldelades under det tidiga 1900-talet rollen som bärare av en nationell identitet. Textilierna ansågs också vara uttryck för en hög konstnärlig kvalitet, särskilt knuten till kvinnor, inte minst genom den omfattande inventering som Lilli Zickerman genomförde 1914-1931 under namnet Sveriges folkliga textilkonst (Svensson \& Waldén 2005; Palmsköld 2007, 2012, 2018; Meister 2012). Inventeringen som bland annat består av dokumentationer av cirka 24000 textila föremål, är sorterad efter tekniker och landskap. Innan inventeringen startade, grundade Lilli Zickerman Föreningen för svensk hemslöjd 1899 som blev startskottet för den svenska hemslöjdsrörelsen. Ett trettiotal hemslöjdsföreningar bildades runt om i landet under 1900-talets första decennier, minst en i varje landskap. Syftet var att fungera som mäklare mellan lokala slöjdare och potentiella kunder och att med utgångspunkt i folkliga slöjd- och hantverkstraditioner, tekniker, material och mönster, utveckla moderna produkter för hemmet (se Palmsköld 2016, 2017). Föreningarna genomförde inventeringar av äldre slöjdtekniker och mönster som låg till grund för egen design anpassad efter samtidens moderna krav på estetik och funktionalitet (ibid.; se även Rosenqvist 2007). I egna butiker såldes dessa produkter och först långt senare, på 1950- och 1960-talen, började material, redskap och beskrivningar att också säljas till kunder som ville slöjda själva. I Hälsingland bildades fem olika föreningar: Arbrå hemslöjdsförening (1908), Bollnäs-Voxnadalens hemslöjdsförening (1907), Föreningen Helsingeslöjd (1911), Västra Hälsinglands hemslöjdsförening (okänt årtal) och Övre Hälsinglands hemslöjdsförening (1911). I grannlandskapet som tillsammans med Hälsingland utgör Gävleborgs län bildades Gästriklands hemslöjdsförening (1912).

Hemslöjdsrörelsen verkade runt om i landet som en aktiv regional och lokal kulturarvsaktör (jfr Lundström 2005b) som, förutom att de sålde produkter som var godkända representanter för god svensk hemslöjd av hög kvalitet, även var engagerad i formandet av en historieskrivning om slöjden och hantverket i Sverige (Palmsköld 2016, 2017). Som tongivande aktör kom rörelsen att bli en auktoritet på området. Den skapade en infrastruktur i form av kunskaper om görande, ett om- 
fattande arkiv med mönster, design och tillverkningsmöjligheter samt verktyg, material och beskrivningar till slöjdade föremål (Palmsköld 2017:27, 37). Hemslöjdsrörelsens främsta fokus låg på det textila området, även om andra slöjder också var representerade. Medlemmarna, liksom ledare och anställda, var till övervägande del kvinnor (Palmsköld 2012) och den textila slöjd de främst arbetade för att dokumentera och utveckla, benämndes i vissa sammanhang kvinnlig slöjd. En av förgrundsgestalterna, Gerda Boëthius (1890-1961), konstaterar i en artikel om hemslöjd att "Hemslöjden är en del av folkkonsten" (Boëthius u.å:457). I Hälsingland kom hemslöjdsföreningarna att fokusera på flera textila tekniker och föremål som förekommer i inredningskulturen. Exempel på detta är broderier som kom att kallas för delsbosöm (Brodén 1979) respektive järvsösöm (se Eldvik \& Åsbrink 1979) och som inventerades och omformades till beskrivningar på bland annat dukar och gardiner.

Hälsinglands folkkultur intresserade inte bara de regionala kulturarvsaktörerna utan även centralt verksamma aktörer. Nordiska museets intresse var primärt riktat mot Dalarna, men även Hälsingland uppmärksammades. Landskapet beskrevs av etnologen Sigurd Erixon, verksam vid Nordiska museet, som "vårt lands förnämaste folkkonstprovins" (Erixon 1929:12). År 1927 hade till exempel "målade tak av framstående bondekonstnärer [...] inkommit från Hälsingland" (Redogörelse för Nordiska museet 1927:9). Intresset gällde då främst norra Hälsingland, socknarna Forsa och Delsbo. Men även från socknarna längre söderut, Trönö, Norrala och Rengsjö, insamlades ett stort antal bemålade skäktknivar. När Delsbogården på Skansen omkring 1940 skulle inredas och möbleras fylldes den med målade möbler och interiörmåleri som valdes ut ur den omfattande samling föremål som redan fanns att tillgå i museets magasin och utställningar.

Under 1960-talet genomförde Ingemar Svensson, dåvarande landsantikvarie i Gävleborgs län, och fotografen Hilding Mickelsson en omfattande inventering av bevarat interiörmåleri ute på gårdarna. Inventeringen låg till grund för boken Hälsingemålningar (Svensson \& Mickelsson 1968) som länge skulle komma att vara den främsta sammanställningen av inredningsmåleriet. Nästa stora inventering genomfördes på 1980- och 1990-talet. Kerstin Sinha vid Ljusdalsbygdens museum tog då initiativ till ett projekt som innebar att måleriet, som till stor del fanns (och fortfarande finns) kvar på ursprunglig plats, inventerades och fotograferades. Materialet digitaliserades för att kunna 
kopplas ihop med andra uppgifter och referenser. Arbetet bedrevs huvudsakligen ideellt genom lokala studiecirklar och i samverkan med studieförbund och hembygdsföreningar med Sinha som samordnare. Varje studiecirkel undersökte sin socken. Resultatet rapporterades till Ljusdalsbygdens museum där bilder och uppgifter kombinerades i en databas. På så sätt kunde uppgifter från länets olika museer och från Nordiska museet samordnas. Materialet har sedan använts av forskare (se t.ex. Andersson 2000; Assis 2014). Det har också presenterats och redovisats i en utställning på Ljusdalsbygdens museum (Medlemsblad för Ljusdalsbygdens museums vänner 1995).

Hälsingegårdarna har även rönt intresse i egenskap av arkitektoniskt kulturarv. Kungliga Konsthögskolan genomförde ett projekt i byggnadsrestaurering 2000-2001. Några av de mer iögonenfallande gårdarna i landskapet mättes då upp och dokumenterades. I samband med projektet beskrevs gårdarna utifrån ett bebyggelseperspektiv och med arkitekturen i fokus (Bedoire \& Hogdal 2000).

\section{Hälsingegården, dess inredning och visuella inredningskultur i forskningen}

Inredningskulturen är alltså tämligen väl dokumenterad och inventerad, främst under 1900-talet. Forskning baserad på materialet har bedrivits både regionalt och centralt - med Nordiska museet som en viktig aktör. När Gästrike-Hälsinge hembygdsförbund konstituerades 1926 ansågs det vara en viktig uppgift att anställa "en vetenskapligt kvalificerad intendent" (Gästrike-Hälsinge hembygdsförbunds arkiv, förslag till stadgar för Gästrike-Hälsinge hembygdsförbund), för den "uttömmande identifiering och katalogisering af samlingarne" som riksantikvarien i en skrivelse 1926 uppmanade till. Tjänsten tillsattes av Mårten Stenberger, arkeolog, som tillsammans med Frans Rodenstam upprättade en ny katalog över samlingarna (Falkstedt 1981:40).

I Sverige har forskningen om folkkonst bedrivits av etnologer, till skillnad från till exempel i Norge där den intresserat konstvetare och räknats in i det designhistoriska fältet. Inredningskulturen i Hälsingland har dock behandlats mer mångsidigt. Som forskningsuppgift har den delats upp mellan arkitekturforskare, konstvetare och etnologer. Perspektiven har varit både estetiska och kulturhistoriska. Olika metoder har använts, skilda teorier om hur estetiska värderingar, hantverkstekniker och stilar spreds, levde kvar och förändrades har avlöst varan- 
dra. Sambandet mellan ekonomisk blomstring och bohagets utveckling har analyserats, nyanserats och ifrågasatts.

Forskningen om Hälsinglands folkkonst har i viss mån gått sin egen väg. I förvånansvärt liten grad har idén om "sjunket kulturgods" och "retardering", ett genomgående tema i den tidigare folklivsforskningens behandling av folkkonsten i andra geografiska områden, präglat forskarnas beskrivning av just Hälsinglands folkkonst. Istället har ett synsätt anammats som mer påminner om senare tiders teorier om identitet och maktstrukturer. Detta illustrerar hur de teoretiska utgångspunkterna har följt förändringar inom humaniora, även om vetenskaplig forskning om folkkonst förändrades genom de vetenskapliga paradigmskiften som skedde i slutet av 1960-talet (jfr Bringéus 2001; Palmsköld 2007).

Tidigt uppmärksammades Hälsinglands särart som ett i folkkonstsammanhang ovanligt "högreståndsbetonat" område. Med detta menas att folkkonsten följde det samtida modet. På 1920-talet noterade Sigurd Erixon hälsingeböndernas "beroende av högreståndsstilarna" som "direktare" än hos till exempel dalfolket (Erixon 1923:73). Manne Östlund noterade hur de olika konsthistoriska stilarna slog igenom med olika kraft i skilda delar av landskapet (Östlund 1953). I Delsbo och Bjuråkers socknar i norr höll sig målarna som var verksamma där till renässansens och barockens formspråk efter det att rokokon slagit igenom i Voxnandalen. Andra forskare har framhållit "pieteten för gamla byggnader och gammalt konsthantverk" som särskilt framträdande i Hälsingland (Telhammer 1982:XVI). Detta har öppnat för ett mer konstvetenskapligt än etnologiskt perspektiv, som påverkat olika forskares sätt att beskriva måleri och folkkonstföremål som "järvsörokoko", "ljusdalsgustavianskt" och "forsaempir". De säregna förstukvistarna har till exempel uppmärksammats och beskrivits på detta sätt (Stackell 1966).

En annan tendens var den fokusering vid enskilda konstnärligt begåvade individer som lyftes fram i en tid då folkkonsten för det mesta beskrevs som ett kollektivt projekt. Vad måleriet beträffar har prioriteringarna handlat om att identifiera namnen bakom verken, till skillnad mot de textila föremålen som har skildrats som en anonym - och kvinnlig - slöjd. Flera namn på målare har förmedlats till eftervärlden genom muntliga berättelser som har traderats och upptecknats. Jonas Åkerström tillskrevs i början av 1800-talet, strax efter sin död, inredningsmåleriet i Kårböle kapell (J. O. Wallin, citerad i Julhälsning till församlingarna i ärkestiftet 1925), ett arbete där denne av allt att döma 
samverkat med sin läromästare Paul Hallberg. Attribueringar har ofta varit dåligt underbyggda, med en tendens till överattribuering till redan värderade och kända målare. Ett exempel på detta är målningarna i Edsbyns hembygdsmuseum, Mårtesgården, som har ansetts vara verk av Jonas Hertman (1755-1804). Detta trots att signaturer saknas och att årtalet 1765 på målningarna talar emot. En betydligt mer kritisk hållning har präglat senare års försök till attribuering.

Genom fördjupade studier i kyrkoräkenskaper och annat skriftligt källmaterial, har fler målare kunnat identifieras. Anders Assis vid Ljusdalsbygdens museum har systematiskt undersökt de muntliga uppgifternas tillförlitlighet genom att granska bygdeforskaren Carl Perssons uppgifter om Ljusdalsbygdens allmogemålare. De insamlade uppteckningarna har ställts i nytt ljus och kombinerats med omsorgsfull analys av bevarade verk. Assis pekar på riskerna med att alltför mycket lita på de muntliga uppgifterna som källa, men understryker samtidigt att "forskningen kring allmogens hantverkare har inte råd att vända denna typ av material ryggen" (Assis 2016).

Parallellt har den biografiska forskningen fortsatt. Elvi Sandbergs och andra släkt- och hembygdsforskares utredningar kring några av målarnas släktförbindelser är ett exempel. Det tidiga 1900-talets uppfattning om folkkonsten som något kollektivt, följt av en fokusering på de enskilda individerna, har idag ersatts av en mer försiktig hållning som innebär att det idag känns mer relevant att beskriva folkkonstnärer som samverkande aktörer i nätverk där det inte alltid går att säga vem som gjort vad.

\section{Hälsingegårdar som världsarv}

Vid UNESCO:s världsarvskommittés möte i S:t Petersburg sommaren 2012 fick Sverige sitt femtonde världsarv under namnet "Decorated Farmhouses of Hälsingland". ${ }^{1}$ Processen ${ }^{2}$ hade pågått i mer än tio år och utnämningen hade föregåtts av en tidigare nominering (se Paju 2016:161ff). Denna nominering från år 2007 omfattade 20 gårdar, linberedningsverk och fäbodar. Beskrivningen ansågs för vag och

1. För en beskrivning av hur utnämningar går till och hur världsarvskonventionen tillämpas, se Paju 2016:64ff.

2. För en analys av hur processen gick till på regional och lokal nivå, se Paju 2016:69ff. 
invändningen mot nomineringen var att hälsingegårdarna inte skilde sig tillräckligt mycket från andra gårdar i Nordeuropa för att tillmätas ett universellt värde (Broström 2013). I den följande omgången hade gårdarnas antal minskats till sju på grund av olika omständigheter och mer betoning hade lagts vid deras unika värden som representanter för en folklig inredningskonst och rumsgestaltning för högtidliga tillfällen. Den motivering som föregick själva utnämningen löd: "The seven selected farms from 1800-1870, which constitute the peak of this cultural expression, are outstanding examples of how independent farmers within a small geographical area combined a highly developed building tradition with a rich folk art tradition in the form of decoratively painted interiors especially for celebrations." (World Heritage List). En intressant iakttagelse är att motiveringen så starkt vilar på en retorik som formades inom den tidiga folklivsforskningen och som blev ett paradigm under 1900-talets första hälft med fokus på bondekulturen och gärna på dess mer spektakulära och estetiskt tilltalande uttrycksformer. Här hade forskningen och museipraktiken gått hand i hand, då samlingar kontinuerligt byggts upp och expanderat enligt principen att prioritera det äldsta och mest dekorerade (Hazelius 1873; Palmsköld 2007).

I världsarvsprocessen fanns ett starkt intresse från regionala aktörer att stärka landskapet som besöksmål och en vilja att profilera sig gentemot länets södra landskap, Gästrikland, med dess kulturarv som snarare präglas av industriminnen (se Paju 2016). Inom världsarvskommittén fanns en enighet om att ha en restriktiv hållning i utnämnandet av fler världsarv i västvärlden. Trots detta ställde sig den svenska regeringen ändå bakom nomineringen med hänvisning till att det här gällde kulturarv i en agrar miljö. Regionen startade Projekt Hälsingegårdar för att koordinera arbetet med tillgänglighetsanpassning och information.

Världsarvsdiskursen och de processer som nominering och utnämning omgetts av och vilka värderingar och maktrelationer som dessa ger uttryck för har analyserats (Turtinen 2006; Ronström 2008; Ronström 2014; Paju 2016). Utnämningen av hälsingegårdar som världsarv och processen som ledde fram till den har beskrivits som en mödosam väg kantad av diskussioner och kompromisser (Andersson \& Aronsson 2009). Den har också beskrivits som exempel på både hur det förgångna (det vill säga hälsingegården som fenomen) befinner sig i och tolkas i samtiden samt används som en resurs för regional och lokal utveckling (se Paju 2016:18f).

Martin Paju har undersökt processerna som ledde fram till världs- 
arvsutnämningen och även hur dessa är kopplade till regional utveckling (Paju 2016). Ett särskilt fokus har legat på vilka värderingar som kommer till uttryck, vilka ideologier de baseras på och vilka olika intressen som varit inblandade i processerna (ibid.). Billy Höök har analyserat hälsingegården som auktoriserad kulturarvsdiskurs, som uttryck för en identitetspolitik och som exempel på hur kulturarv definieras utifrån ett estetiserande synsätt (Höök 2015:4ff). Han menar att världsarvet främst bör ses som "en framställning av ett varumärke" - varumärket Hälsingland (Höök 2015:64).

Kulturarvsprocesser i västvärlden är ofta knutna till offentliga institutioner som museer, regionala aktörer som länsstyrelser och statliga myndigheter som Riksantikvarieämbetet (se Grahn 2011; Paju 2016:20ff). De representerar en officiell version av historien genom sin verksamhet, denna är också inskriven i samlingar och platser eller besöksmål med kulturarvsstatus (Grahn 2011:224). Laurajane Smith kallar denna officiella version för "authorised heritage discourse" (Smith 2006). Innebörden i detta är, enligt Smith, att kulturarvsprocesser ofta startar och genomförs på initiativ av organisationer och myndigheter och inte av de personer som är inblandade och berörs av resultatet. Föremålen och platserna som har utnämnts som kulturhistoriskt intressanta och värda att samla in och skydda, representerar olika idéer om samhälle, kultur och människor som har utvecklats och förändrats över tid (se Kirshenblatt-Gimblett 1998). De innehåller därför även gamla och till och med övergivna idéer och uppfattningar inlåsta i bevarad bebyggelse, i arkiv och föremålssamlingar och även om de inte längre är giltiga, är de på många sätt levande (Palmsköld et al. 2016). Paju menar att "En världsarvsutnämning baseras på förväntade värden av olika slag" (Paju 2016:19) och vidare att det handlar om att uppfylla krav baserade på en normativ syn på autenticitet (ibid. 2016:54). Enligt Paju syns detta i nomineringstextens formuleringar som speglar ett äldre och beprövat sätt att tala om företeelsen hälsingegård.

Det går alltså inte att bortse ifrån att det finns och har funnits synpunkter på urvalet av gårdar, på avgränsningen som motiveringen ger uttryck för, på hur ord som "hälsingegård" och "folkkonst" definieras. Men nomineringen kan också ses som ett erkännande av den folkliga dekorationskonstens förmåga att väcka och aktivera antikvariers, hembygdsforskares och andra kulturarvsaktörers intressen och handlingskraft. 


\section{Referenser}

\section{Otryckta källor}

Hälsinglands museums arkiv (HM). Anna Lindegrens arkiv, A 24:19. Manus till en berättelse om buföringen från fäbodvallen.

Gästrike-Hälsinge hembygdsförbunds arkiv. Inkommande skrivelser 1926: förslag till stadgar för Gästrike-Hälsinge hembygdsförbund.

Hälsinglands fornminnessällskaps arkiv. Inkomna skrivelser 1926: Skrivelse från tillförordnade riksantikvarien; Inkomna skrivelser 1867-1973: Brev från Bernhard Sahlin 1909; Inkommande skrivelser 1927: Skrivelse till Kungl. Maj:t från Gästrike-Hälsinge hembygdsförbund, koncept; Protokoll: 23 augusti 1861; 16 december $1861 ; 16$ september $1862 ; 18$ september $1862 ; 30$ december $1897 ; 29$ december $1902 ; 28$ december 1904; 20 februari 1909; 15 mars 1910; 8 mars 1918; 27 februari 1934; Årsberättelse 1903; Verksamhetsberättelse 1923; Stadgar för Helsinglands Fornminnes-Sällskap. Af Sällskapet gillade och antagna den 17 December 1860 och den 6 Juni 1863.

\section{Tryckta källor}

Andersson, Maj-Britt (2000). Allmogemålaren Anders Ädel. Diss. Uppsala: Uppsala universitet.

Andersson, Maj-Britt \& Inga-Lill Aronsson (2009). Why World Cultural Heritage? Democracy, local participation and knowledge production in the world culture nomination of farms in Hälsingland, Sweden. Paper to the 16th International Congress of Anthropological and Ethnological Sciences (IUAES). Kunming, China, 27-31 juli 2009 .

Arcadius, Kerstin (1997). Museum på svenska: länsmuseerna och kulturhistorien. Diss. Lund: Lunds universitet.

Assis, Anders \& Owe Norberg (2014). Mats, Anders och Järvsömolnen. Ljusdal: Ljusdalsbygdens museum.

Assis, Anders (2016). Ljusdals många allmogemålare och bygdeforskaren Carl Perssons källvärde. Hälsingerunor 2016.

Bedoire, Fredric \& Lis Hogdal (2000). Den stora hälsingegården: gårdar och befolkning $i$ Voxnans dalgång. Stockholm: Byggförlaget.

Berglin, Elisabeth (2000). En bonadsmålare och hans värld: Johannes Nilsson i Breared. Diss. Lund: Lunds universitet.

Boëthius, Gerda (u.å.). Hemslöjden. u.o.: s. 453-482.

Bringéus, Nils-Arvid (red.) (2001). Sigfrid Svensson som folklivsforskare: en minnesskrift $i$ anledning av hundraårsdagen av hans födelse den 1 juni 1901. Uppsala: Gustav Adolfs akademi.

Bringéus, Nils-Arvid (2005). Folkkonst och forskning: en tillbakablick. Formgivare: folket. s. [16]-29.

Brodén, Märta (1979). Delsbosöm: långsöm och tofssöm från Delsbo. 2 uppl. Stockholm: LT.

Broström, Ingela (2013). Kulturarv i världsklass. Bygd och natur 2013:2, s. [8]-11.

Cajmatz, Karl (1965). Bondeslottet. Svenska Turistföreningens årsskrift 1965. 
Carlsson, Gustaf \& Adrian Molin (1909). Svenska allmogehem. Stockholm: Fritze.

Danielson, Sofia (1986). Stina Rodenstam: ideolog och organisatör i 1900-talets hemslöjdsarbete. Stockholm: Nordiska museets förlag.

Danielson, Sofia (2005). Ideologer i olika tider: om Sophie Adlersparre, Stina Rodenstam och Anna-Maja Nylén. I: Svensson, Birgitta \& Louise Waldén (red.). Den feminina textilen: makt och mönster. Stockholm: Nordiska museets förlag, s. $47-70$.

Daun, Johannes \& Christer Ahlberger (red.) (2018). Bondeherrgårdar: den nyrika bondeklassens gårdar 1750-1850. Lund: Nordic Academic Press.

Eldvik, Berit \& Brita Åsbrink (1979). Järvsösöm. Stockholm: LT.

Engberg, Arthur (1941). Tal vid Delsbogårdens invigning. Fataburen: kulturhistorisk tidskrift. Stockholm: Nordiska museet.

Erixon, Sigurd (1923). Hälsingarnas hem. I: Boheman, Ezaline (red.). Svenska Turistföreningens årsskrift 1923. Stockholm: Wahlström \& Widstrand, s. [52]-84.

Erixon, Sigurd (1929). En bondgård av hälsingesnitt. I: Wallin, Sigurd \& Sigurd Erixon (red.). Svenska kulturbilder, bd I. Stockholm: Skoglunds bokförlag.

Falkstedt, Karin (1980). Hälsinglands fornminnessällskaps historia, I. Meddelanden frän Hälsinglands museum 1980.

Falkstedt, Karin (1981). Hälsinglands fornminnessällskaps historia, II. Meddelanden från Hälsinglands museum 1981.

Fiebranz, Rosemarie (2003). Hälsinglands kultur - hälsingegårdarnas kultur? Myter och motbilder. Bebyggelsehistorisk tidskrift 2003:45, s. 103-116.

Grahn, Wera (2011). Intersectionality and the Construction of Cultural Heritage Management. Archeologies 2011:7(1), s. 222-250.

Gustafsson, Gotthard (1941). Delsbogården. Fataburen: kulturhistorisk tidskrift. Stockholm: Nordiska museet.

Hazelius, Artur (1873). Några anvisningar vid samlandet af folkdrägter och bohag m.m. I: Skandinavisk-etnografisk samling i hufvudstaden. Stockholm: P. A. Norstedt \& söner.

Helsingerunor: hembygdsorgan för helsingarne (1921). Edsbyn: Ovanåkers hembygdsförening.

Hemslöjdens samlingar, www.digitaltmuseum.se [2018-04-19].

Höök, Billy (2015). Rum för fest och föreställning: framställningen av världsarvet Hälsingegårdar (Göteborgs universitet, Institutionen för kulturvård 2015). Göteborg: Göteborgs universitet, Institutionen för miljövetenskap och kulturvård.

Julhälsning till församlingarna i ärkestiftet. (1925). Uppsala: Uppsala ärkestift.

Kirshenblatt-Gimblett, Barbara (1998). Destination Culture: Tourism, museums, and heritage. Berkeley: University of California Press.

Knutsson, Johan (1995). Dalmålningar i Nordiska museet. I: Bringéus, Nils-Arvid \& Margareta Tellenbach. Dalmålningar i jämförande perspektiv: Föreläsningar vid bildsymposiet $i$ Falun och Leksand den 13-16 september 1992. Falun: Dalarnas museum, s. 32-41.

Knutsson, Johan (2010). I "hemtrefnadens" tid: allmoge, nationalromantik och konstnärligt nyskapande i arkitektur, möbler och inredningar 1890-1930. Stockholm: Nordiska museet. 
Londos, Eva (2005). Folkkonst och populärkonst: en samtidsblick. Fataburen: kulturhistorisk tidskrift. Stockholm: Nordiska museet, s. 30-37.

Lundström, Catarina (2005a). Den hemvävda kulturen: kulturarvsfältet i Jämtlands län 1860-1940: en kalender, ett persongalleri och en reflektion över den "jämtländska regionalismen". I: Evergård, Mikael (red.). Kulturarv och historiebruk, s. 10-51. Östersund: Jamtli.

Lundström, Catarina (2005b). Fruars makt och omakt: kön, klass och kulturarv 19001940. Diss. Umeå: Institutionen för historiska studier, Umeå universitet.

Malmsten, Carl (1916). Om svensk karaktär inom vår konstkulturen - särskildt i hemmets utformning. Svenska Slöjdföreningens tidskrift 1916.

Medlemsblad för Ljusdalsbygdens museums vänner 1995:2. Ljusdal: Ljusdalsbygdens museums vänner.

Meister, Anna (red.) (2012). Lilli \& Prinsen: 100 år av hemslöjd och textil konst. Stockholm: Carlssons.

Nilson, Allan T. (2001). Möten med Sigfrid Svensson: några episoder. I: Bringéus, Nils-Arvid (red.). Sigfrid Svensson som folklivsforskare: en minnesskrift i anledning av hundraårsdagen av hans födelse den 1 juni 1901 (Acta Academiae Regiae Gustavi Adolphi, 78). Uppsala: Gustav Adolfs akademi.

Nylander, Lars \& Karin Abenius Falkstedt (2009). Hälsinglands museum 150 år. Hälsingerunor 2009, s. 5-13.

Nyström, Ingalill (2012). Bonadsmåleri under lupp: spektroskopiska analyser av färg och teknik i sydsvenska bonadsmålningar 1700-1870. Diss. Göteborg: Göteborgs universitet. Tillgänglig på: http://hdl.handle.net/2077/30154

Nyström, Ingalill, Johan Knutsson, Anneli Palmsköld \& Christina Linscott (2018). Hälsingegården och den färggranna folkkonsten. I: Daun, Johannes \& Christer Ahlberger (red.). Bondeherrgårdar. Den nyrika bondeklassens gårdar 1750-1850. Lund: Nordic Academic Press.

Ohlén, Carl-Eric, Waldemar Sydow \& Sten Björkman (1940). Svenska gods och gårdar, del 34, Hälsingland med Orsa finnmark. Uddevalla: Svenska gods och gårdar.

Olsson, Daniel (2002). Hälsinglands bostadshus under 1700-talet (Göteborgs universitet, Institutionen för kulturvård 2002:33). Göteborg: Göteborgs universitet, Avdelningen för kulturvård, Institutionen för miljövetenskap och kulturvård.

Olsson, Daniel \& Bertil Thelin (2000). Hälsinglands bostadshus under 1600-talet (Göteborgs universitet, Institutionen för kulturvård 2000:8). Göteborg: Göteborgs universitet, Avdelningen för kulturvård, Institutionen för miljövetenskap och kulturvård.

Paju, Martin (2016). Hälsingegården i omvandling: en studie av världsarvsprocessen $i$ Hälsingland. Diss. (sammanfattning) Uppsala: Sveriges lantbruksuniversitet. Tillgänglig på: http://urn.kb.se/resolve?urn=urn:nbn:se:slu:epsilon-e-3427

Palmsköld, Anneli (2005a). Hängkläden, drättar, lister och takdukar: inredningstextilier i ny belysning. I: Svensson, Birgitta \& Louise Waldén (red.). Den feminina textilen: makt och mönster. Stockholm: Nordiska museets förlag, s. 141-162.

Palmsköld, Anneli (2005b). Textil som folkkonst. Fataburen: kulturhistorisk tidskrift. Stockholm: Nordiska museet, s. 92-102.

Palmsköld, Anneli (2007). Textila tolkningar: om hängkläden, drättar, lister och takdukar. Diss. Lund: Lunds universitet. 
Palmsköld, Anneli (2012). Begreppet hemslöjd. Stockholm: Hemslöjdens förlag.

Palmsköld, Anneli (2016). Craft, crochet and heritage. I: Palmsköld, Anneli, Johanna Rosenqvist \& Gunnar Almevik (red.) (2016). Crafting Cultural Heritage. Göteborg: Göteborgs universitet, Institutionen för kulturvård.

Palmsköld, Anneli (2017). Den omoraliska virkningen. I: Jönsson, Lars-Eric (red.). Politiska projekt, osäkra kulturarv: kampanjer och förhandlingar $i$ det sena 1900-talets Sverige och Europa. Lund Studies in Arts and Cultural Sciences 14.

Palmsköld, Anneli (2018). Lilli Zickerman. Svenskt kvinnobiografiskt lexikon. https:// skbl.se/sv/artikel/LilliZickerman [2018-04-16].

Palmsköld, Anneli, Johanna Rosenqvist \& Gunnar Almevik (red.) (2016). Crafting Cultural Heritage. Göteborg: Göteborgs universitet, Institutionen för kulturvård.

Redogörelse för Nordiska museet. Fataburen: kulturhistorisk tidskrift. Stockholm: Nordiska museet.

Riegl, Alois (1894/1978). Volkskunst, Hausfleiss und Hausindustrie. Mittenwald: Mäander Kunstverlag.

Ronström, Owe (2008). Kulturarvspolitik: Visby. Från sliten småstad till medeltidsikon. Stockholm: Carlsson Bokförlag.

Ronström, Owe (2014). Consequences of World Heritage Production: The heritage town. Primitive tider (specialutgåva), s. 7-17.

Rosenqvist, Johanna (2007). Könsskillnadens estetik? Om konst och konstskapande i svensk hemslöjd på 1920- och 1990-talen. Diss. Lund: Lunds universitet.

Rydin, Lena (2009). Karin Larssons värld. Utök. och bearb. utg. Stockholm: Bonnier fakta.

Schissler, Pehr (1749). Hälsinga hushåldning i korthet författad af Pehr Schissler. ... Tryckt uti kongl. tryckeriet. 1749. Stockholm.

Schissler, Pehr (1769). Gästrikelands $i$ wissa delar goda och $i$ andra àter förbättring tarfwande hushåldning, utgifwen och til trycket befordrad af Pehr Schissler, ... [Stockholm], tryckt uppå bokhandlaren Carl Gottf. Schindlers eget förlag.

Smith, Laurajane (2006). Uses of Heritage. New York: Routledge.

Stackell, Lars (1966). Förstukvistar $i$ Hälsingland: uppsats för högre seminariet $i$ konsthistoria vid Göteborg universitet, höstterminen 1936. Göteborg: Göteborgs universitet.

Strömberg, Elisabeth (1941). Möbleringen av Delsbogården. Fataburen: kulturhistorisk tidskrift. Stockholm: Nordiska museet.

Svensson, Ingemar \& Hilding Mickelsson (1968). Hälsingemålningar. Stockholm: LT.

Telhammer, Ingrid (1982). Efterreformatorisk träskulptur i Hälsingland. I: Kilström, Bengt Ingmar (red.). Hälsinglands kyrkor, bd 3 [nr 29-40]. Uppsala: Stiftsbyrån.

Tengbom, Ivar, John Åkerlund \& Gustaf Carlsson (1912). Gamla svenska allmogehem. Stockholm: I distr. hos Fritzes bokförlag.

Turtinen, Jan (2006). Världsarvets villkor: intressen, förhandlingar och bruk i internationell politik. Diss. Stockholm: Stockholms universitet. Tillgänglig på: http://urn. $\mathrm{kb}$.se/resolve?urn=urn:nbn:se:su:diva-1248

World Heritage List. Tillgänglig på: www.unesco.org [2018-05-17].

Zickerman, Lilli (1918): Den svenska hemslöjdens ortskaraktärer. I: Hemslöjdskom- 
mitténs betänkande avgivet den 10 december 1917, del 1. Stockholm: Nordiska bokhandeln, s. 193-230.

Åkerlund, John (1912). Våra gamla allmogehem. I: Boheman, Ezaline (red.). Svenska Turistföreningens årsskrift 1912. Stockholm: Wahlström \& Widstrand.

Ålund, Otto Wilhelm (red.) (1875). Uppfinningarnas bok: öfversigt af det industriela arbetets utveckling på alla områden, bd 6, Råämnenas mekaniska bearbetning. Register till uppfinningarnas bok, bd 1-6. Stockholm: Linnström.

Östlund, Manne (1953). Dekorativt inredningsmåleri i Hälsinglands bondehem. Hälsingerunor 1953. 